\title{
Regulation of Hippocampal Synaptic Strength by Glial xCT
}

\author{
느eena E. Williams and David E. Featherstone \\ Department of Biological Sciences, University of Illinois at Chicago, Chicago, Illinois 60607
}

\begin{abstract}
Most extracellular glutamate in the brain is released by xCT, a glial antiporter that exports glutamate and imports cystine. The function of xCT, and extracellular glutamate in general, remains unclear. Several lines of evidence suggest that glutamate from xCT could act in a paracrine fashion to suppress glutamatergic synapse strength by triggering removal of postsynaptic glutamate receptors. To test this idea, we used whole-cell patch-clamp electrophysiology and immunohistochemistry to quantify receptor number and synapse function in xCT knock-out mouse hippocampal CA3-CA1 synapses. Consistent with the hypothesis that xCT suppresses glutamate receptor number and synapse strength, xCT knock-out synapses showed increased AMPA receptor abundance with concomitant large enhancements of spontaneous and evoked synaptic transmission. We saw no evidence for changes in GABA receptor abundance or the overall number of glutamatergic synapses. The xCT knock-out phenotype was replicated by incubating slices in the xCT inhibitor $(S)$-4carboxyphenylglycine, and consistent with the idea that xCT works by regulating extracellular glutamate, the xCT knock-out phenotype could be reproduced in controls by incubating the slices in glutamate-free aCSF. We conclude that glutamate secreted via xCT suppresses glutamatergic synapse strength by triggering removal of postsynaptic AMPA receptors.
\end{abstract}

Key words: glutamate; synaptic; $\mathrm{xCT}$

\section{Introduction}

Approximately $80 \%$ of synapses in the mammalian brain use glutamate as a neurotransmitter. However, most extracellular glutamate in the brain is nonsynaptic (Timmerman and Westerink, 1997; Jabaudon et al., 1999; Shinohara et al., 2000; Baker et al., 2002; Fillenz, 2005; Montana et al., 2006; Qin et al., 2013). Nonsynaptic glutamate can be released from neurons and glia, via many molecular mechanisms (Kimelberg et al., 1990; Baker et al., 2002; Parpura et al., 2004; Montana et al., 2006; Malarkey and Parpura, 2008; Bridges et al., 2012), but over half of it is attributable to cystine-glutamate antiporters (Baker et al., 2002; Piyankarage et al., 2008; De Bundel et al., 2011; Massie et al., 2011).

Cystine-glutamate antiporters are plasma membrane protein complexes that secrete glutamate and import cystine (Sato et al., 1999, 2000, 2002; Kanai and Endou, 2001; Kim et al., 2001; Hosoya et al., 2002). The functional core of these transporters is xCT, a predicted 12 transmembrane protein required for amino acid selectivity (Sato et al., 1999; Chillarón et al., 2001; Wagner et al., 2001; Verrey et al., 2004; Palacín et al., 2005; Fernández et al., 2006). Consistent with the idea that xCT is important for brain function, xCT expression is highest in brain tissue (Sato et al.,

Received March 28, 2014; revised 0ct. 1, 2014; accepted 0ct. 20, 2014.

Author contributions: L.E.W. and D.E.F. designed research; L.E.W. and D.E.F. performed research; L.E.W. and D.E.F. contributed unpublished reagents/analytic tools; L.E.W. and D.E.F. analyzed data; L.E.W. and D.E.F. wrote the paper.

This project was supported by a National Alliance for Research on Schizophrenia and Depression Independent Investigator Award, Alexander von Humboldt Foundation Award, and University of Illinois at Chicago LAS Award for Faculty of Sciences to D.E.F. Thanks to Dr. Hideyo Sato for $x \mathrm{XT}^{-/-}$mutant mice and Dr. Richard Huganir for GluA1 phospho-T840 "penta" mutant mice. Thanks also to Dr. Janet Richmond for comments on this manuscript.

The authors declare no competing financial interests.

Correspondence should be addressed to David E. Featherstone, UIC Biological Sciences, Room 4311 SEL (MC 067), 950 South Halsted Street, Chicago, IL 60607.E-mail: def@uic.edu.

DOI:10.1523/JNEUROSCI.1267-14.2014

Copyright $\odot 2014$ the authors $\quad 0270-6474 / 14 / 3416093-10 \$ 15.00 / 0$
2002; Burdo et al., 2006; La Bella et al., 2007). Unfortunately, no antibodies reliably recognize xCT protein in situ. However, antibodies against the selective $\mathrm{xCT}$ substrate $\alpha$-aminoadipic acid show strong specific staining in rat brain glia, including Bergmann glia in the cerebellum and astrocytes in cerebral cortex, corpus callosum, and surrounding hippocampal CA1 pyramidal cells (Pow, 2001). In contrast, mature neurons exhibit little or no apparent $\mathrm{xCT}$ activity and accumulate cystine through alternative systems, including the excitatory amino acid transporters (EAATs) responsible for glutamate uptake after synaptic transmission (Zerangue and Kavanaugh, 1996; Pow, 2001; McBean, 2002; Chen and Swanson, 2003; Verrey et al., 2004).

Presumably, xCT-secreted glutamate plays an important part in brain function, though the exact role remains unclear. Possibilities include activating ionotropic glutamate receptors to depolarize cells (Warr et al., 1999) or activating metabotropic receptors that subsequently modulate neurotransmission (Baker et al., 2002). Several lines of evidence from Drosophila suggest that xCT-secreted glutamate suppresses glutamatergic synapse strength by triggering removal of postsynaptic glutamate receptors, and that this can regulate behavior in ways not previously thought possible (Augustin et al., 2007; Grosjean et al., 2008; Chen et al., 2009). But this hypothesis has never been tested in mammals.

To test whether $\mathrm{xCT}$ regulates glutamatergic synapse strength by suppressing postsynaptic glutamate receptor abundance in mammals, we examined hippocampal CA3-CA1 synapses in mice lacking xCT. We found increased postsynaptic AMPA receptor abundance with commensurate enhancement in glutamatergic synaptic strength. This phenotype was reproduced when brain tissue was treated with the $\mathrm{xCT}$ inhibitor CPG, or when tissue was incubated in aCSF lacking glutamate. We conclude that glutamate secreted by glial xCT suppresses postsynaptic glu- 
tamate receptor abundance to regulate glutamatergic synapse strength in vivo.

\section{Materials and Methods}

Mouse strains. All procedures were reviewed and approved by the University of Illinois at Chicago Animal Care and Use Committee. xCT knock-out mice (Slc7a11 ${ }^{\text {tm1Hsat; }}$ RRID:MGI_MGI:3608978) were generously provided by Hideyo Sato, Yamagata University, Japan (Sato et al., 2005). The xCT knock-out mutation was generated in the C57BL/6J background and outcrossed with C57BL/6J $>10$ times. $\mathrm{xCT}$ expression is completely eliminated in these $\mathrm{xCT}^{-1-}$ mice. Homozygous C57BL/6J mice were used as controls. GluA1 phospho-T840 "penta" mutant mice (Lee et al., 2007) were kindly provided by Rick Huganir's lab at Johns Hopkins University. These mice were developed from RRID:IMSR_JAX:008892.

Slice preparation. To obtain brain tissue, male P14-P22 mice were anesthetized with isoflurane and decapitated. Whole brains were then immediately removed and the hippocampus isolated. A vibrating microtome was used to prepare $300-\mu \mathrm{m}$-thick hippocampal slices in icecold cutting and storage solution containing the following (in $\mathrm{mm}$ ): 87 $\mathrm{NaCl}, 2.5 \mathrm{KCl}, 7 \mathrm{MgCl}_{2}, 75$ sucrose, 25 glucose, $1.25 \mathrm{NaH}_{2} \mathrm{PO}_{4}, 26$ $\mathrm{NaHCO}_{3}$, and $0.5 \mathrm{CaCl}_{2}$. Slices were then immersed in freshly prepared aCSF at an osmolarity of 300-305 mOsm ( $2 \mathrm{~mm} \mathrm{CaCl}, 124 \mathrm{~mm} \mathrm{NaCl}, 26$ mм $\mathrm{NaHCO}_{3}, 3 \mathrm{~mm} \mathrm{KCl}, 1.25 \mathrm{NaH}_{2} \mathrm{PO}_{4}, 1 \mathrm{~mm} \mathrm{MgSO}_{4}$, and $10 \mathrm{~mm}$ glucose) at $35^{\circ} \mathrm{C}$ for $30-45 \mathrm{~min}$, after which they were allowed to reach room temperature. $95 \% \mathrm{O}_{2} / 5 \% \mathrm{CO}_{2}$ was bubbled through all solutions.

Electrophysiology. All electrophysiological recordings were obtained via whole-cell patch-clamp of CA1 pyramidal cells, using conventional techniques. Recordings were performed in freshly prepared aCSF bubbled with $95 \% \mathrm{O}_{2} / 5 \% \mathrm{CO}_{2}$. Patch pipettes (5-8 $\mathrm{m} \Omega$ ) were filled with 270 mOsm internal solution containing the following (in $\mathrm{mM}$ ): 120 K-gluconate, $10 \mathrm{KOH}, 9 \mathrm{KCl}, 3.48 \mathrm{MgCl}_{2}, 4 \mathrm{NaCl}$, and $10 \mathrm{~mm}$ HEPES. AMPA receptor currents were recorded from cells voltage clamped at $-70 \mathrm{mV}$, in bath solution containing $10 \mu \mathrm{m}$ bicuculline (to block $\mathrm{GABA}_{\mathrm{A}}$ receptors) and (when mEPSCs were recorded) $1 \mu \mathrm{M}$ TTX (to block presynaptic action potentials). Bath application of NBQX was used as a control to confirm that currents were attributable to AMPA receptor activity. NMDA receptor currents were recorded from cells voltage clamped at $+50 \mathrm{mV}$, in bath solution containing $10 \mu \mathrm{M}$ bicuculline and $5 \mu \mathrm{M}$ CNQX, a competitive AMPA receptor antagonist. mIPSCs were recorded from cells voltage clamped at $100 \mathrm{mV}$, in bath solution containing $5 \mu \mathrm{M}$ CNQX and $1 \mu \mathrm{M}$ TTX. Bicuculline was bath applied as a control to ensure that mIPSCs were attributable to $\mathrm{GABA}_{\mathrm{A}}$ receptor activity. Stimulus-evoked EPSCs were generated by delivering a stimulatordriven current pulse to CA3 axons via a patch electrode filled with extracellular aCSF. Where noted, slices were incubated in aCSF containing 50 $\mu \mathrm{M}$ CPG for $1.5-3 \mathrm{~h}$. When glutamate-containing aCSF was used, slices were incubated in aCSF containing $5 \mu \mathrm{M}$ glutamate for $4.5 \mathrm{~h}$, then $15 \mathrm{~min}$ minimum in glutamate-free aCSF for patch clamping. All electrophysiological recordings and analysis were performed using pClamp 10 software (Molecular Devices). mEPSCs, mIPSCs, and sEPSCs were detected and measured using Event Analysis tools in pClamp 10 software. Amplitude and frequency measurements are averages from all events that occurred during at least $100 \mathrm{~s}$ of continuous recording.

Immunohistochemical analysis and confocal microscopy. For immunohistochemical detection and quantification of synaptic proteins, mouse coronal brain sections were fixed in 4\% PFA, $\mathrm{pH} 7.4$, for $18-24 \mathrm{~h}$. Sections were cryoprotected overnight in PBS containing 30\% sucrose and $0.02 \% \mathrm{NaN}_{3}$, then frozen at $-20^{\circ} \mathrm{C}$. For staining and imaging, $40 \mu \mathrm{m}$ hippocampal slices were cut from the frozen sections on a sliding microtome, then incubated for $1 \mathrm{~h}$, free floating in a blocking solution of PBS, pH 7.4, containing $0.025 \%$ Triton X-100 and 5\% BSA. After blocking, slices were incubated for $18-24 \mathrm{~h}$ in blocking solution containing primary antibodies. The primary antibodies used for this study were as follows: mouse anti-synapse-associated protein-102 (SAP-102; 1:500; University of California Davis/NIH NeuroMab \#75-058; RRID: AB_2261666); mouse monoclonal anti-synapsin (1:100; synaptic systems \#106001; RRID:AB_2200566); rabbit anti-glutamate receptor 1, AMPA subtype phospho T840 (1:1000; Abcam \#ab12108; RRID: AB_2113448); and rabbit anti-glutamate receptor 1, AMPA subtype (1:
500; Abcam \#ab31232; RRID:AB_2113447). After incubation in primary antibodies, slices underwent four 10 min washes in PBS plus 5\% BSA at room temperature. Slices were then incubated for $2 \mathrm{~h}$ in PBS solution containing 5\% BSA and appropriate fluorescently conjugated secondary antibodies (1:400; Jackson ImmunoResearch; TRITC- and CY5conjugated anti-mouse or anti-rabbit). Secondary fluorophores were switched for half of all preparations in each set of experiments, to control for possible differences in baseline fluorescence or secondary antibody immunoreactivity. After incubation with secondary antibodies, slices were washed four times in PBS at room temperature and placed onto slides. Images of hippocampal Shaffer collateral-CA1 synaptic regions were generated using laser-scanning fluorescence microscopy at $540 \times$ magnification. The size of synaptic puncta was measured by manually delineating the edges of puncta using ImageJ software and calculating the enclosed area based on pixel dimensions. Only puncta where the GluA1 immunoreactivity (either GluA1 or T840) was colocalized with SAP-102 were used for measurements. Synaptic density was measured by counting the number of GluA1+SAP-102 puncta per micrometer squared.

Statistical analysis. For all experiments, $N=$ the number of mice (e.g., $N=5$ means that measurements were taken from five different mice). For immunohistochemical experiments, three slices were used from each mouse for each measurement. Measurements were taken from all three slices and then averaged to equal $1 \mathrm{~N}$. Unless stated otherwise, a Student's $t$ test was used for statistical comparisons. For analysis of data with unequal variances (as determined by a post hoc $F$ test), a Mann-Whitney $U$ test was used. Kolmogorov-Smirnov tests were used to compare distributions. For comparison of input-output curves (stimulation intensity vs EPSC amplitude) an ANOVA was performed. Results were considered statistically significant when the $p$ value $\leq 0.05$. RRID $=$ Research Resource Identifier (https://www.force11.org/node/4463).

\section{Results}

We hypothesized that loss of xCT would lead to accumulation of postsynaptic glutamate receptors at hippocampal synapses. Arguably the most precise and quantitative method for detecting changes in postsynaptic glutamate receptors is measurement of mEPSC amplitudes. We therefore recorded mEPSCs from whole-cell patch-clamped (holding potential - $70 \mathrm{mV}$ ) CA1 pyramidal neurons in hippocampal slices (Fig. 1A). To ensure that the mEPSCs were due to glutamate receptor activity, the $\mathrm{GABA}_{\mathrm{A}}$ receptor antagonist bicuculline was added to the bath. Also, mEPSCs were completely eliminated in the presence of $5 \mu \mathrm{M}$ NBQX, demonstrating that they were due to AMPA receptor activity (Fig. 1B). Consistent with our hypothesis, mEPSC amplitudes from $\mathrm{xCT}^{-1-}$ mice were significantly larger than those recorded from C57BL/6J controls (control $=6.2 \pm 0.3 \mathrm{pA}, N=$ $8 ; \mathrm{xCT}^{-/-}=9.8 \pm 0.9 \mathrm{pA}, N=8 ; p=0.003$ ). Interestingly, much of the increase in $\mathrm{xCT}^{-1-} \mathrm{mEPSC}$ amplitudes was attributable to an increase in larger mEPSCs rather than a uniform shift in mEPSC amplitude (Fig. 1D,E). This increase was highly significant (Kolmogorov-Smirnov test, $p<0.0001$ ). We detected no change in mEPSC kinetics (control decay time $=9.94 \pm 0.87 \mathrm{~ms}$, $N=8 ; \mathrm{xCT}=10.01 \pm 0.98 \mathrm{~ms}, N=8 ; p=0.958$ ).

To rule out the possibility that the increase in $\mathrm{xCT}^{-1-}$ mEPSC amplitudes might be due to factors unrelated to glutamate receptor function, we performed additional measurements. First, we considered hippocampal cell capacitance, which is a measure of cell size and voltage-clamp efficacy. However, $\mathrm{xCT}^{-1-}$ mutants and controls showed no measureable difference in average cell capacitance, despite consistently larger mEPSC amplitudes in $\mathrm{xCT}^{-1-}$ mutant mice (Fig. $1 F$ ). The enhanced mEPSC amplitudes in $\mathrm{xCT}^{-1-}$ recordings also remained elevated relative to controls despite variation in time before initiation of recording (Fig. 1G) and leak currents amplitude (Fig. 1H). We conclude that mEPSCs are inherently larger in $\mathrm{xCT}^{-/-}$mutant mice, despite variation in methodological factors, consistent with the idea 
A

A

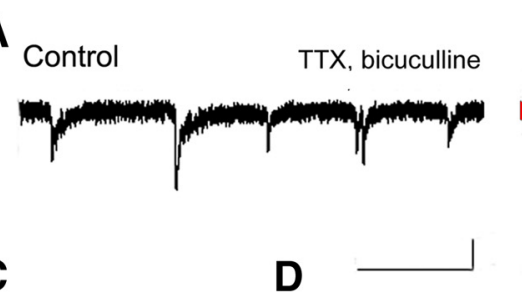

C

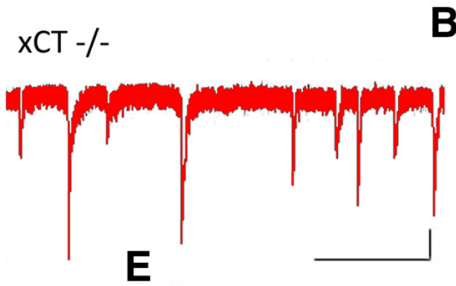

B

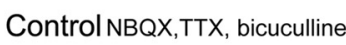
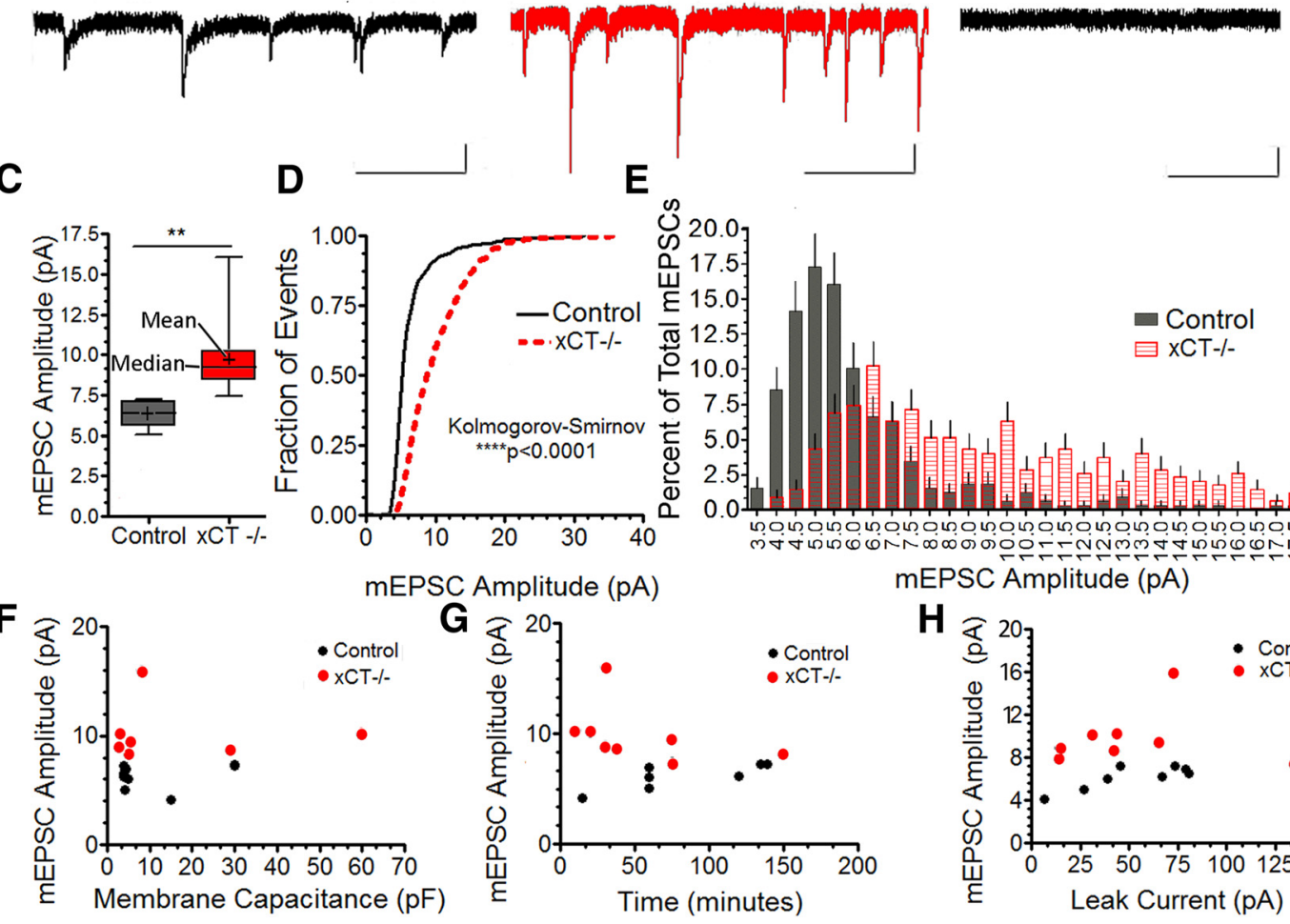

$\mathbf{F}$

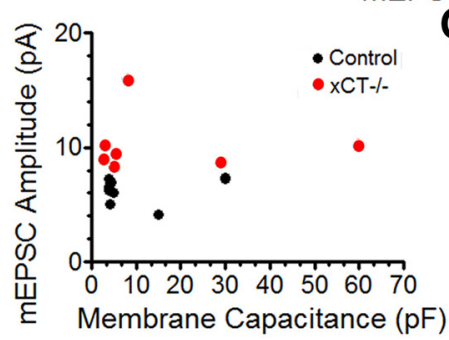

C Amplitude (pA)

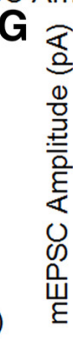

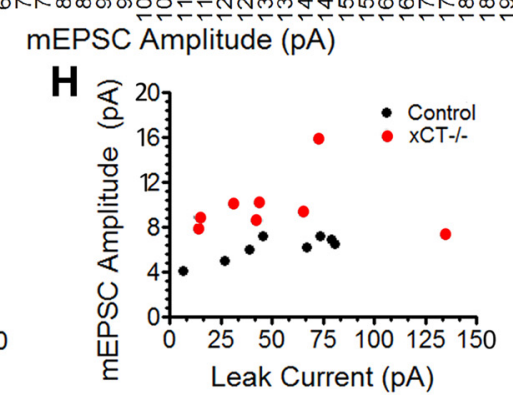

Figure 1. AMPA receptor mEPSC amplitudes are increased in $\mathrm{xCT}{ }^{-1-}$ mutant mice compared with controls. $A$, Representative whole-cell patch-clamp $(-70 \mathrm{mV})$ recordings of control (black) and $\mathrm{xCT}^{-1-}$ mutant (red) mEPSCS in CA1 of the hippocampus. Events were recorded in the presence of $1 \mu \mathrm{m}$ TTX to block presynaptic action potentials and $10 \mu \mathrm{m}$ bicuculline to block $\mathrm{GABA}_{\mathrm{A}}$ receptors. Calibration: Horizontal, $1000 \mathrm{~ms}$; vertical, 5 PA. B, mEPSCs in the presence of $5 \mu \mathrm{MNBQX}$, an AMPA receptor antagonist. C, Box-and-whisker plots of mEPSCs amplitudes. The bottom and top of the box are always the first and third quartiles, and the band inside the box is always the second quartile (the median). + , Denotes the mean. D, Cumulative frequency distribution of $m E P S C$ amplitudes. $\boldsymbol{E}$, mEPSC amplitude histogram. $\boldsymbol{F}, \mathrm{mEPSC}$ amplitude (pA) versus cell capacitance (pF). $\boldsymbol{G}, \mathrm{mEPSC}$ amplitude (pA) versus time until $\mathrm{mEPSC}$, were recorded from slice. $\boldsymbol{H}$, $\mathrm{mEPSC}$ amplitude $(\mathrm{pA})$ versus leak current $(\mathrm{pA})$.

that hippocampal CA1 neurons in $\mathrm{xCT}^{-1-}$ mice contain more postsynaptic glutamate receptors.

The anatomical complexity of hippocampal slices makes reliable staining and identification of postsynaptic receptors challenging due to multiple layers of overlapping cell processes and synapses. Nevertheless, we reasoned that increased postsynaptic glutamate receptor abundance in $\mathrm{xCT}^{-1-}$ mutant mouse hippocampi should be measurable using confocal microscopy and commercially available antibodies against GluA1 protein, a postsynaptic AMPA receptor subunit in hippocampal CA3-CA1 synapses. Eighty-one percent of postsynaptic AMPA receptors in CA1 neurons are thought to contain GluA1 (Lu et al., 2009). As expected, GluA1 immunoreactivity was abundant in appropriate regions of hippocampal neuropil, and most of this immunoreactivity was absent when slices were treated with fluorescently conjugated secondary antibodies but not primary antibodies (Fig. $2 C$ ). To determine how much of the remaining putative GluA1 receptor immunoreactivity represented synaptically localized GluA1 protein, we colabeled slices with antibodies to either the presynaptic vesicle-associated protein synapsin, or the PSD scaffolding protein SAP-102 (Fig. 2A). SAP-102 was used because it is known to be abundant in the CA1 synapses of the immature (P14-P22) mice used in this study, and then replaced later in development by PSD-95 (Elias et al., 2006). Immunoreactivity for synapsin and SAP-102 was also abundant in the hippocampal neuropil. Some of the synapsin and SAP-102 immunoreactivity was associated with GluA1 immunoreactivity, and was in the size range expected for synaptic protein clusters within the resolution limits of standard confocal microscopy (Fig. 2C). Further, where synapsin immunoreactivity was associated with GluA1 immunoreactivity, the two clusters of immunoreactivity tended to be adjacent, as one would expect for presynaptic and postsynaptic proteins. In contrast, where SAP-102 immunoreactivity was associated with GluAl immunoreactivity, the clusters tended to be overlapping. However, not all GluA1 and synapsin and SAP-102 immunoreactivity was associated with each other (Fig. $2 B, C$ ), consistent with the idea that nonassociated immunoreactivity was nonspecific or nonsynaptic. Therefore, only GluA1 immunoreactivity that clearly overlapped SAP-102 immunoreactivity was assumed to be a reliable measure of GluA1 abundance (Fig. 2C).

As further confirmation that this subset of GluAl immunoreactivity truly represented postsynaptic GluA1 protein, we repeated the staining using antibodies that specifically recognize T840-phosphorylated (T840-P) GluA1, which is thought to be localized exclusively in postsynaptic densities (Lee et al., 2007). Consistent with this idea, a much greater proportion of the T840-P GluA1 immunoreactivity was associated with SAP-102. To ensure that the T840-P GluA1 antibodies were specific for T840-P GluA1 in situ, we tested these antibodies in slices from T840A mutant mice, wherein GluA1 cannot be phosphorylated. In these T840A mutants, the T840-P antibody staining was reduced to background fluorescence levels (Fig. 2C). Based on these experiments, we concluded that we can reliably quantify synaptic GluAl immunoreactivity in hippocampal slices by restricting our analysis to the subset of GluA1 puncta that colocalize with SAP-102, with the most reliable measurements coming from the subset of 


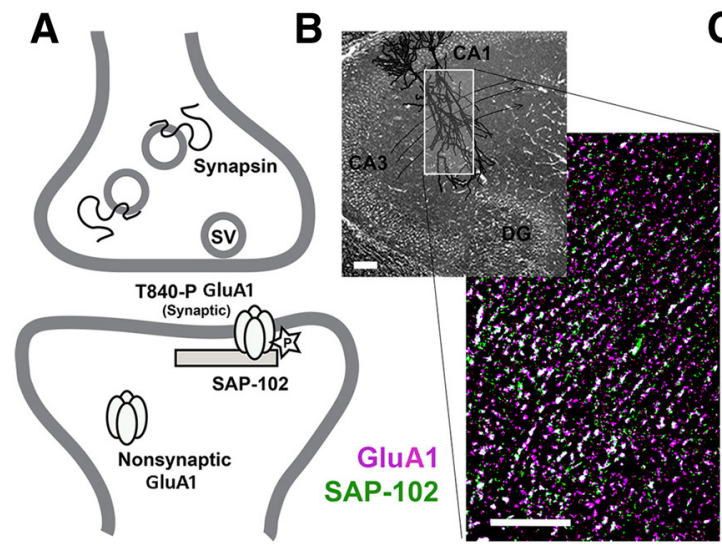

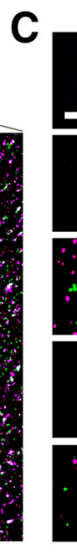

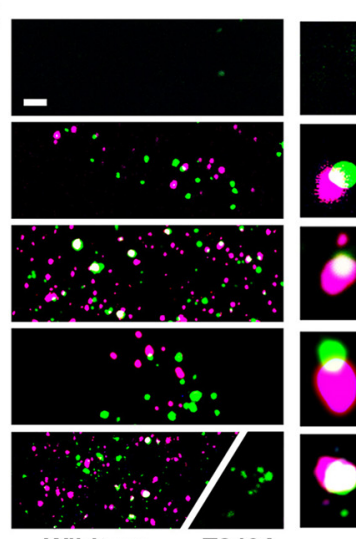

Fluorescent secondary antibodies alone

GluA1 + Synapsin

GluA1 + SAP-102

T840-P GluA1 + Synapsin

T840-P GIuA1 + SAP-102

Figure 2. Postsynaptic AMPA receptors in CA3-CA1 synapses can be visualized in hippocampal slices. $A$, Diagram of a presynaptic bouton and postsynaptic dendritic spine, illustrating the presynaptic and postsynaptic locations of synapsin, SAP-102, GluA1 AMPA receptor subunits, and T840-P GluA1 AMPA receptor subunits. B, Top, Confocal image of a hippocampal slice, overlaid with a diagram showing the relationship between CA3 inputs to CA1 dendrites. Scale bar, $50 \mu \mathrm{m}$. Bottom, Representative GluA1 (pink) and SAP-102 (green) immunostaining in the neuropil at low magnification. Scale bar, $10 \mu \mathrm{m}$. C, Top, Staining of fluorescent secondary antibodies alone in control mice. Second from the top, Staining GluA1 (pink) and synapsin (green). Third from the top, Staining of GluA1 (pink) and SAP-102 (green). Fourth from the top, Staining of T840-P GluA1 (pink) and synapsin (green). Bottom, Staining of T840-P GluA1 (pink) and SAP-102 (green). Middle, T840A mutant slices stained with antibodies against T840-P GluA1 (pink) and SAP-102 (green). Scale bar, $1 \mu \mathrm{m}$.

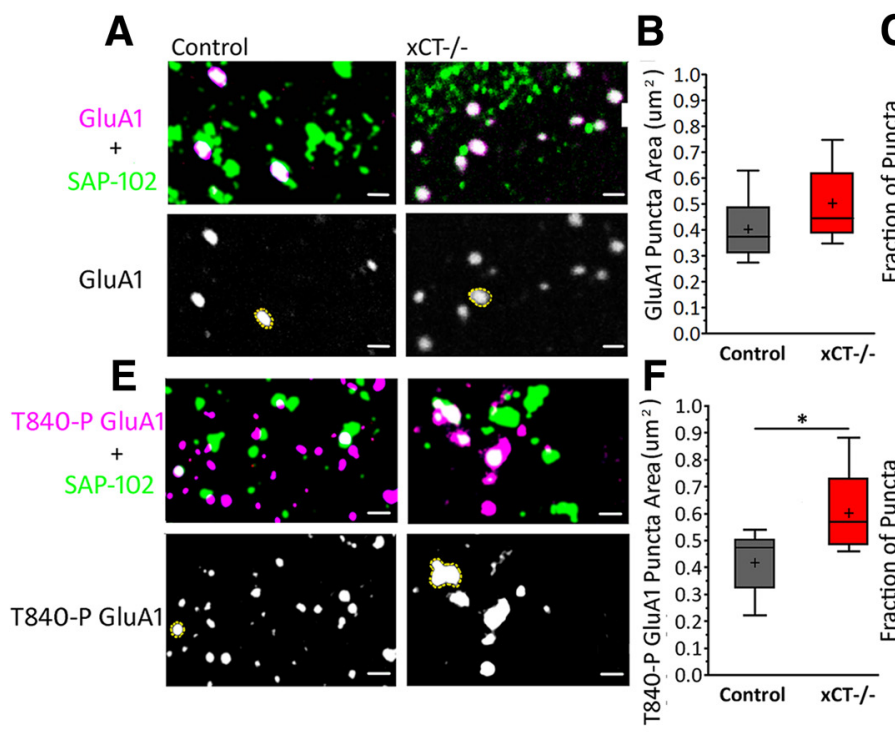

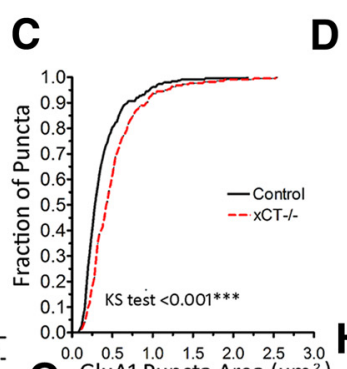
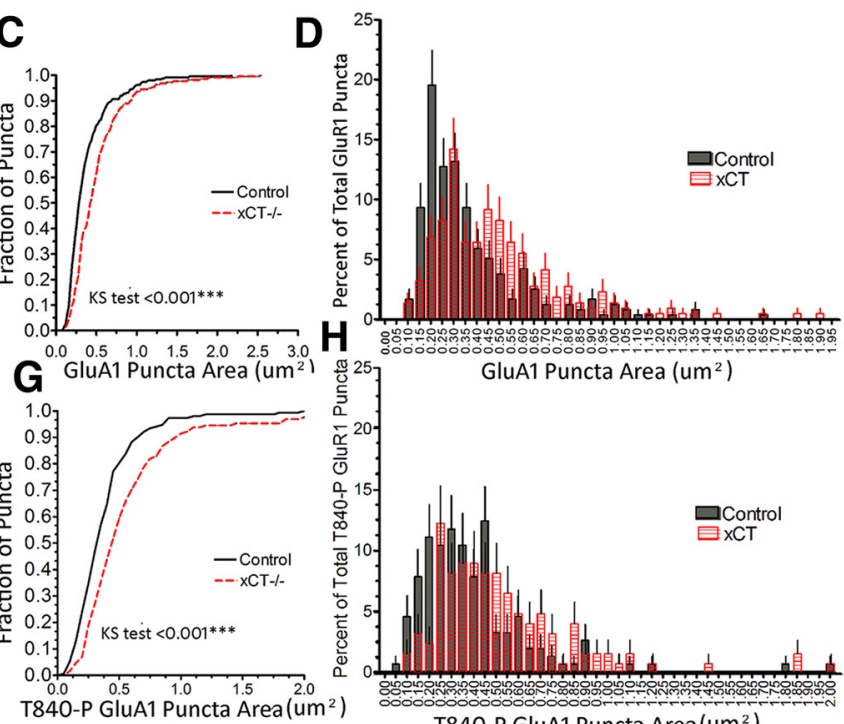

Figure 3. Immunohistochemistry shows larger synaptic GluA1 puncta in $\mathrm{x} \mathrm{CT}^{-1-}$ mutant mice, compared with controls. $A$, Top, GluA1 (pink) and SAP-102 (green) immunostaining in CA1 dendritic region. White shows overlap. Bottom, Dashed yellow line shows example of measured puncta area. B, Box-and-whisker plot of synaptic GluA1 puncta size in controls and xCT ${ }^{-1-}$ mutant CA1 dendritic regions. $C$, Cumulative frequency histogram of GluA1 puncta sizes. D, Histogram of GluA1 puncta sizes. $\boldsymbol{E}-\boldsymbol{H}$, As in $\boldsymbol{A}-\boldsymbol{D}$, except using antibodies that specifically recognize T840-P GluA1. Scale bars: $1 \mu \mathrm{mm}$.

T840-P GluA1 puncta that colocalize with SAP-102. All of our subsequent analysis was therefore restricted to these two classes of puncta.

Figure 3 shows confocal images of CA1 dendritic regions in hippocampal slices stained with antibodies against SAP-102 and either GluA1 or T840-P GluA1. In agreement with the idea that $\mathrm{xCT}^{-1-}$ mutant synapses contain more GluA1, we observed larger GluA1 puncta in $\mathrm{xCT}^{-/-}$mutant mice (Fig. $3 A-C$ ). The shift in the GluA1 puncta size distribution (Fig. $3 C$ ) was statistically significant (Kolmogorov-Smirnov test, $p<0.001$ ), but the shift in average puncta size did not reach statistical significance (Fig. $3 B$; $\mathrm{xCT}^{-l-}=0.41 \pm 0.04 \mu \mathrm{m}^{2}, N=8$ mice; control = $0.50 \pm 0.06 \mu \mathrm{m}^{2}, N=8$ mice; $p=0.198$ ), possibly because nonphosphorylated GluA1 staining represents both nonsynaptic and synaptic GluA1. Consistent with this idea, both the puncta size distribution and average puncta size were significantly al- tered for T840-P GluA1 (Fig. 3E; control $=0.42 \pm 0.04 \mu \mathrm{m}^{2}$, $N=7$ mice; $\mathrm{xCT}^{-1-}=0.61 \pm 0.06 \mu \mathrm{m}^{2}, N=6$ mice; $p=0.029$; Fig. 3F; Kolmogorov-Smirnov test, $p<0.001$ ), suggesting that most of the change was exclusively postsynaptic. The magnitude of the T840-P GluA1 increase was 31\%, statistically indistinguishable from the increase in mEPSC size measured electrophysiologically (Fig. 1), in support of the conclusion that there are more postsynaptic glutamate receptors in $\mathrm{xCT}^{-1-}$ mutant hippocampal CA3-CA1 synapses.

To explore whether loss of xCT might lead to changes in abundance of other types of receptors, we recorded CA1 neuron mIPSCs, which are mediated by $\mathrm{GABA}_{\mathrm{A}}$ receptors. This required the addition of the AMPA receptor blocker CNQX to the recording solution, and a change in holding potential to $-100 \mathrm{mV}$, because the reversal potential of chloride in our recording conditions was near $-70 \mathrm{mV}$. The inward currents measured under 

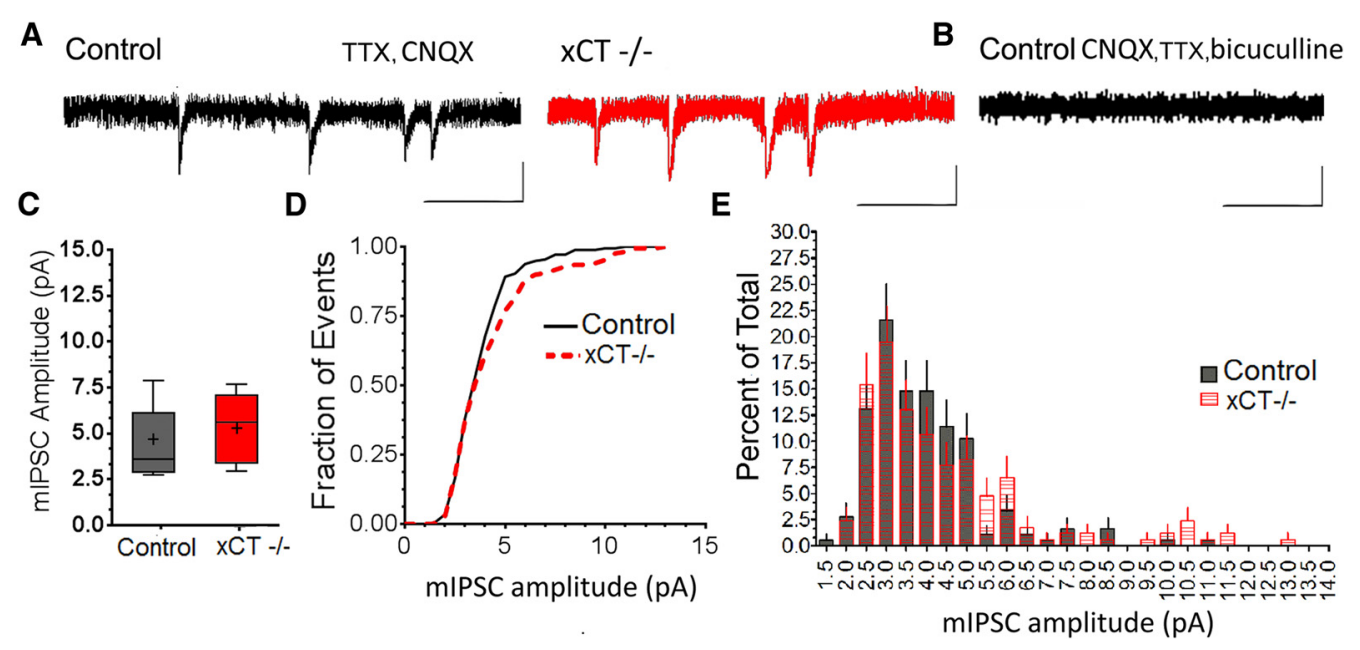

Figure 4. $\mathrm{mIPSC}$ amplitudes show no change between $\mathrm{xCT}{ }^{-1-}$ mutants and controls. $\boldsymbol{A}$, Representative whole-cell voltage-clamp $(-100 \mathrm{mV})$ recordings from CA1 cells taken from control (black) and $\mathrm{xCT}^{-1-}$ mutant (red) slices. Events were recorded in the presence of $1 \mu \mathrm{M}$ TTX, to block presynaptic action potentials, and $5 \mu \mathrm{m}$ CNQX, a competitive AMPAR antagonist. $\boldsymbol{B}$, Bicuculline $(10 \mu \mathrm{M})$ was bath applied as a control to ensure that mIPSCs were attributable to $\mathrm{GABA}_{\mathrm{A}}$ receptor activity. $C$, Box-and-whiskers plot showing no significant difference in mIPSC current amplitude. $D$, Cumulative frequency distribution of mIPSC amplitudes. $\boldsymbol{E}$, mIPSC amplitude histogram.

these conditions (Fig. 4A) were confirmed to be $\mathrm{GABA}_{\mathrm{A}}$ receptor-mediated mIPSCs by their complete elimination in bicuculline (Fig. 4B). Consistent with the idea that loss of $\mathrm{xCT}$ does not lead to changes in GABA receptor abundance, at least in hippocampal CA1 neurons, we measured no significant change in mIPSC current amplitude (Fig. $4 C-E$; controls $=4.3 \pm 0.8 \mathrm{pA}$, $N=6 ; \mathrm{xCT}^{-l-}=5.3 \pm 0.7 \mathrm{pA}, N=6$; Kolmogorov-Smirnov test, $p=0.148$ ). We also detected no change in mIPSC kinetics (control decay time $=10.62 \pm 1.14 \mathrm{~ms}, N=6 ; \mathrm{xCT}=12.19 \pm 1.12$ ms, $N=6 ; p=0.35$ ).

The electrophysiological and immunohistochemical data described above strongly suggest that hippocampal CA3-CA1 postsynaptic AMPA receptor abundance is increased by approximately one-third after loss of xCT. This is a biologically significant increase, on par with changes thought to occur during processes such as learning and memory, and raises the possibility that XCT might be an important regulator of synaptic strength in vivo. However, a change in postsynaptic glutamate receptor abundance might not necessarily result in a physiologically relevant change in synaptic function. The probability of presynaptic neurotransmitter release could drop to compensate for more receptors, for example, or the overall number of synapses between cells could be reduced. Alternatively, the effects of increased receptor number might be mitigated by restrictions imposed by synaptic architecture and glutamate diffusion (Savtchenko and Rusakov, 2014). We therefore wondered whether xCT mutant mice might not show physiologically relevant changes in CA3CA1 synaptic function despite an increase in postsynaptic glutamate receptor numbers.

First, we measured spontaneous synaptic activity (sEPSCs) using the same procedures used to record mEPSCs, but leaving out the TTX to permit endogenous neuronal activity (Fig. 5). sEPSC amplitudes in $\mathrm{xCT}^{-1-}$ mutant mice were significantly larger than those measured from controls (Fig. $5 A, B$; control = $\left.10.4 \pm 1.2 \mathrm{pA}, N=9 ; \mathrm{xCT}^{-1-}=16.5 \pm 2.6 \mathrm{pA}, N=7 ; p=0.035\right)$, and the entire sEPSC amplitude distribution in $\mathrm{xCT}^{-1-}$ mutant mice was shifted toward larger events (Fig. 5C,D; KolmogorovSmirnov test, $p<0.0001$ ). There was no significant change in sEPSC frequency (Fig. $5 E$; control $=0.59 \pm 0.20 \mathrm{~Hz}, N=9$; $\mathrm{xCT}=0.67 \pm$ $0.17, N=7 ; p=0.79)$.
To test whether electrical stimulation of presynaptic inputs would lead to larger EPSCs in $\mathrm{xCT}^{-1-}$ mice, we used an open patch-style electrode filled with extracellular bath solution to deliver electrical pulses to Schaffer collateral CA3 axons, while simultaneously recording EPSCs in postsynaptic CA1 cells. The average EPSC amplitude in $\mathrm{xCT}^{-/-}$mutants was approximately double that measured in controls (Fig. $6 A, B$; control $=115.6 \pm$ $15.4 \mathrm{pA}, N=7 \mathrm{xCT}^{-1-}=222.7 \pm 47.1 \mathrm{pA}, \mathrm{N}=7$; MannWhitney test $p=0.017$ ), and the entire EPSC distribution was shifted toward larger values (Fig. 6C,D; Kolmogorov-Smirnov test, $p<0.0001)$. To ensure that the changes in EPSC amplitude were not due to better stimulation efficacy in $\mathrm{xCT}^{-1-}$ mutants, we collected EPSC amplitudes at multiple stimulation intensities. EPSC amplitude was consistently increased in $\mathrm{xCT}^{-1-}$ mutants independent of stimulation intensity (ANOVA $p=0.002$ ), to approximately double that of controls.

We measured a one-third increase in average mEPSC amplitude, but a doubling of EPSC amplitude (Fig. 6). This apparent discrepancy might initially be attributed to presynaptic changes. However, as shown in Figure 1E, mEPSC amplitude distributions are highly skewed, and most of the change in average $\mathrm{xCT}^{-/-}$ mutant mEPSC amplitude was due to the addition of larger mEPSCs rather than a shift in the entire mEPSC amplitude distribution. Similarly, the shift in average postsynaptic GluA1 puncta size that we measured was due mostly to the addition of larger puncta (Fig. 3F). These results suggest that the predominant change in $\mathrm{xCT}^{-/-}$mutants was the addition of a few receptors to many synapses, and the addition of many receptors to a few synapses. Under these conditions, it is expected that the change in average EPSC amplitude will be larger than the change in average mEPSC amplitude, because each EPSC represents activation of many synapses and therefore has a higher likelihood of including contributions from the moststrengthened synapses, compared with individual mEPSCs. By the same argument, we expect the change in sEPSC amplitudes to be intermediate between the change in mEPSC and EPSC amplitudes, because sEPSCs represent activation of an intermediate number of synapses. Since this is exactly what we observed, our results are consistent with the idea that increased sEPSC and EPSC amplitudes in $\mathrm{xCT}^{-1-}$ mutant mice 
A

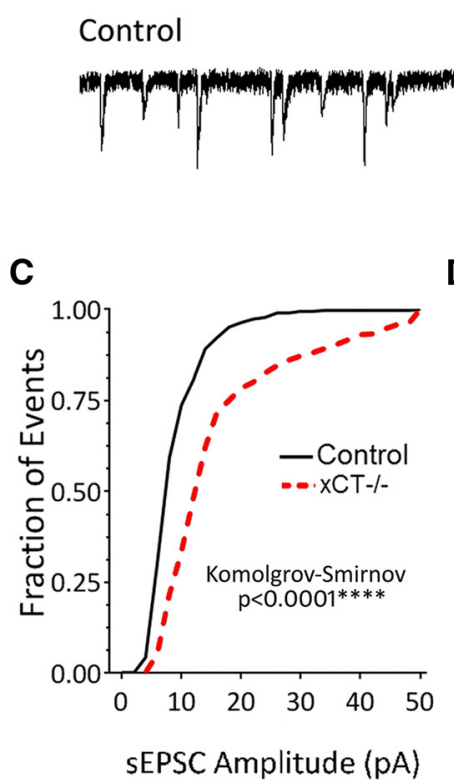

$$
\text { xCT-/- }
$$

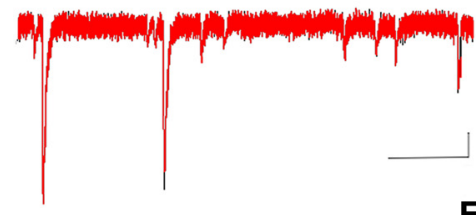

D 15

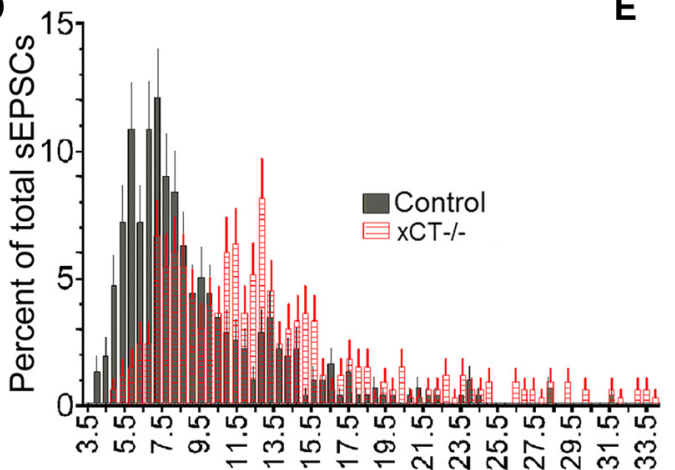

sEPSC Amplitude (pA)
B
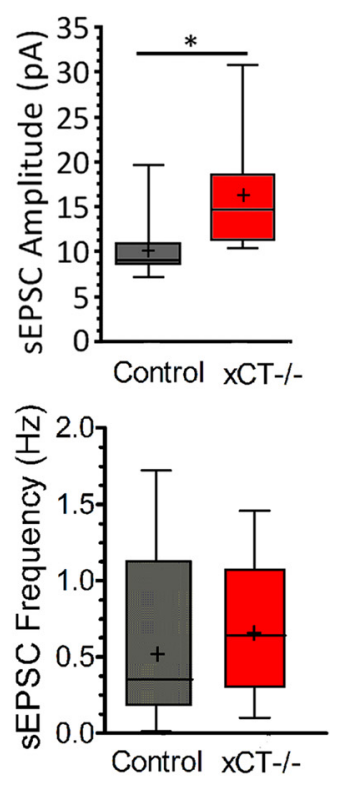

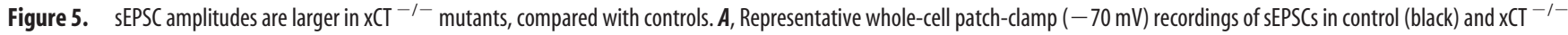
mutant (red) CA1 neurons. Calibration: Horizontal, $1000 \mathrm{~ms}$; vertical, 5 pA. B, Box-and-whisker plot of sEPSC amplitudes. C, Cumulative frequency distribution of sEPSC amplitudes. D, sEPSC amplitude histogram. $E$, Box-and-whiskers plot comparing control and $\mathrm{xCT}^{-/-}$mutant sEPSC frequencies.

are due entirely to postsynaptic addition of AMPA receptors, without any presynaptic changes.

Nevertheless, we wondered whether increased EPSC amplitudes in $\mathrm{xCT}^{-1-}$ mutants might also be caused by changes in presynaptic function or overall synapse number. Therefore, we looked for differences in paired-pulse facilitation, synapse density, and postsynaptic current frequency. There was no obvious change in paired-pulse ratio (control EPSC2/ EPSC1 $=1.34 \pm 0.07, N=5 ; \mathrm{xCT}=$ $1.20 \pm 0.02, N=2 ; p=0.272$ ). There was also no significant difference between the density of synaptic GluA1 puncta in controls and $\mathrm{xCT}^{-1-}$ mutants, regardless of whether puncta were quantified using either GluA1 or T840-P GluA1 antibodies (Fig. $7 A, B$; control GluA1/SAP-102 puncta density $=0.02 \pm 0.003 / \mu \mathrm{m}^{2}, N=$ 8; xCT GluA1/SAP-102 puncta density = $0.02 \pm 0.002 / \mu \mathrm{m}^{2}, N=8 ; p=0.604$; control T840-P GluA1/SAP-102 puncta density $=0.01 \pm 0.001 / \mu \mathrm{m}^{2}, N=7$; $\mathrm{xCT}$ T840-P GluA1/SAP-102 puncta density = $\left.0.01 \pm 0.001 / \mu \mathrm{m}^{2}, N=6 ; p=0.824\right)$. Control and $\mathrm{xCT}^{-1-}$ mutants also showed no difference in mEPSC, mIPSC, or sEPSC frequency (Fig. 7C,D; mEPSC frequency: control = $0.29 \pm 0.08 \mathrm{~Hz}, N=12 ; \mathrm{xCT}=0.39 \pm 0.27 \mathrm{~Hz}, N=12 ; p=$ 0.722; mIPSC frequency: control $=0.28 \pm 0.09 \mathrm{~Hz}, N=6$; $\mathrm{xCT}=0.21 \pm 0.07 \mathrm{~Hz}, N=7 ; p=0.534 ;$ sEPSC frequency: control $=0.59 \pm 0.20 \mathrm{~Hz}, N=9 ; \mathrm{xCT}=0.67 \pm 0.17, N=7 ; p=$ $0.79)$.

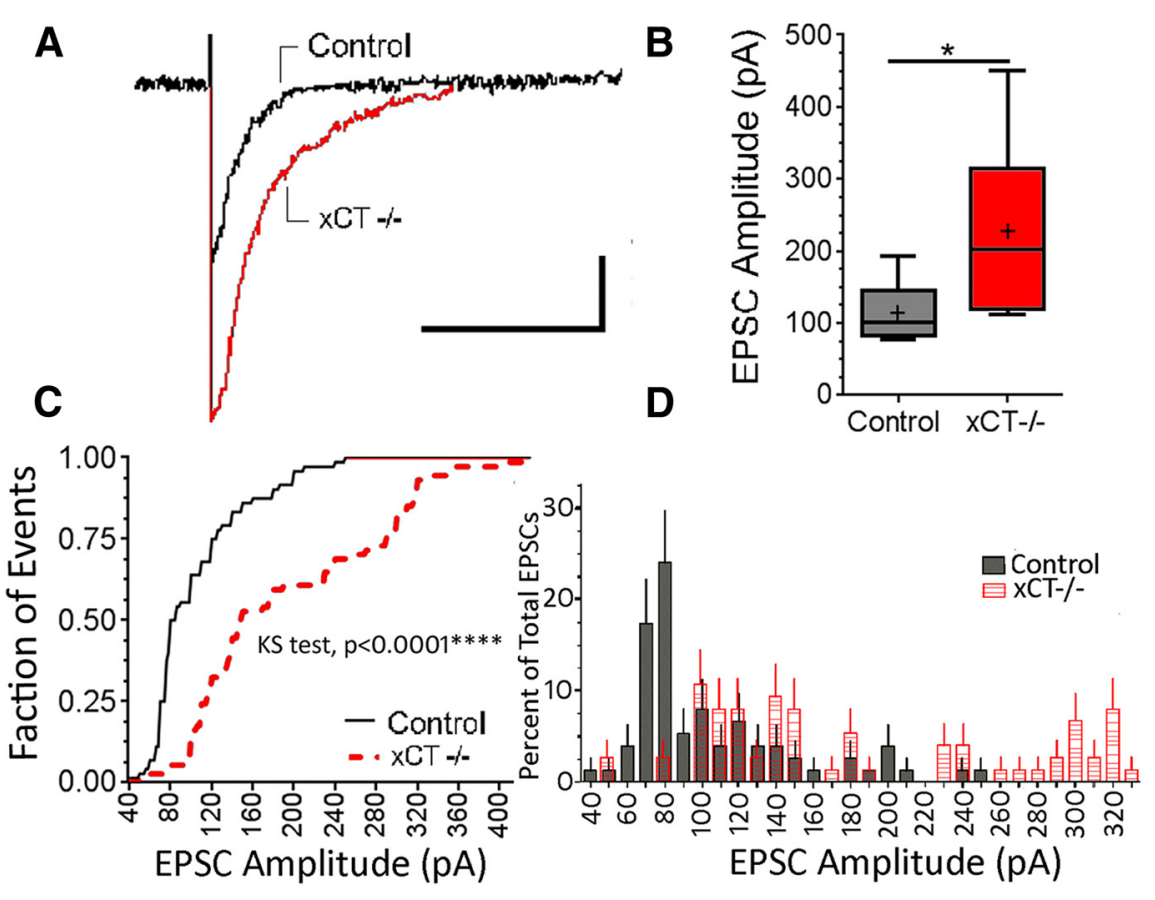

Figure 6. Evoked EPSC amplitudes are larger in $\mathrm{xCT^{-1- }}$ mutants, compared with controls. $\boldsymbol{A}$, Representative whole-cell patch-clamp $(-70 \mathrm{mV})$ recordings of stimulus-evoked EPSCs in control (black) and $\mathrm{xCT}{ }^{-/-}$mutant (red) CA1 neurons. Calibration: Horizontal, $100 \mathrm{~ms}$; vertical, 50 pA. B, Box-and-whiskers plot comparing control and $x \mathrm{CT}^{-/-}$mutant EPSC amplitudes. $\boldsymbol{C}$, Cumulative frequency distribution of EPSC amplitudes. D, sEPSC amplitude histogram.

Our data suggest that the increased transmission in $\mathrm{xCT}^{-1-}$ mutant CA3-CA1 synapses can be attributed mostly if not entirely to an increase in postsynaptic CA1 neuron AMPA receptors. If $\mathrm{xCT}$ activity suppresses postsynaptic AMPA receptor abundance, then it presumably does via the glutamate that it pumps into the extracellular space. To test this idea, we tried several types of experiments. 
A
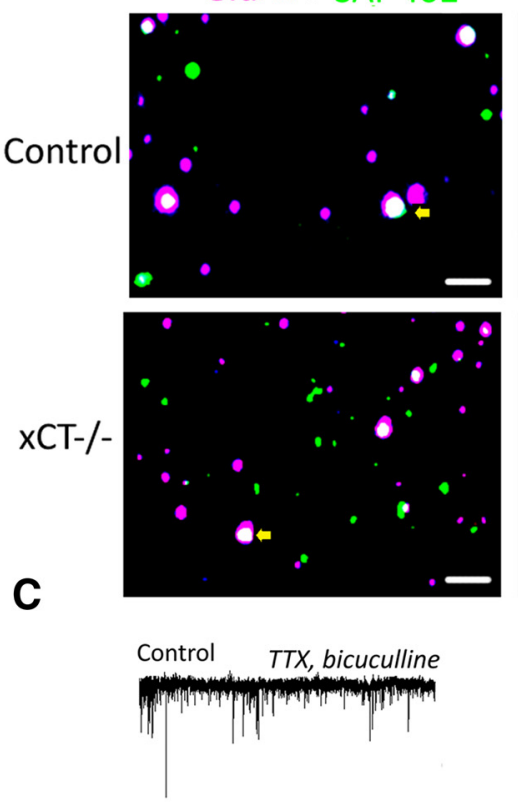

xCT-/-

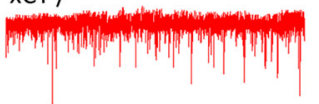

T840-P GluA1+ SAP-102
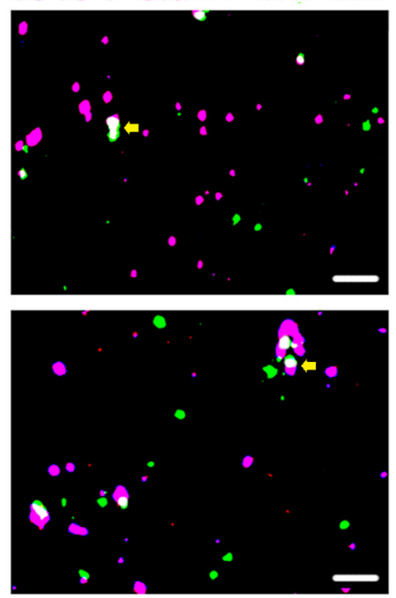

Control

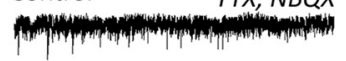

$x \mathrm{CT}-1-$

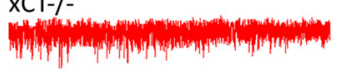

B

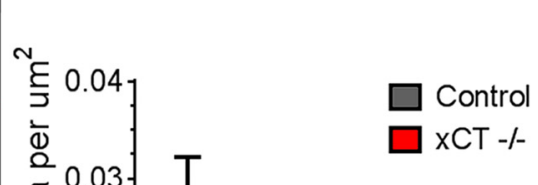

Control

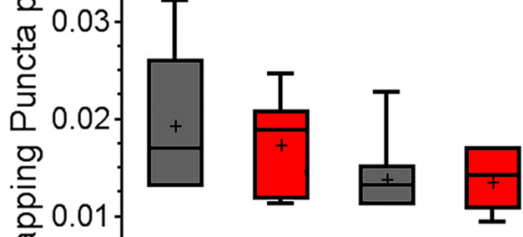

0.00

GluA1 T840-P GluA1

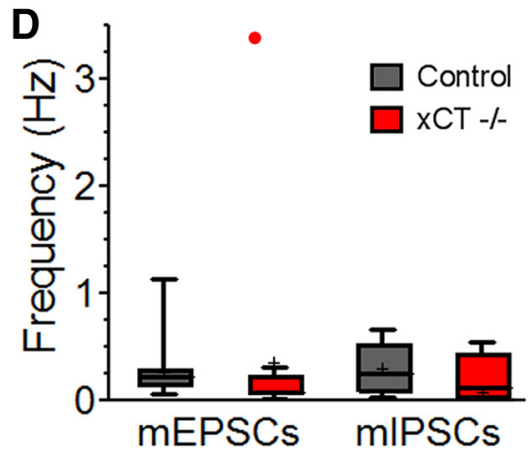

Figure 7. No evidence for increased synapse density in $\mathrm{xCT}^{-/-}$mutants, compared with controls. $A$, Representative images of $\mathrm{xCT}^{-/-}$mutant and control slices stained with SAP-102 (green) and either GluA1 (left, pink) or T840-P GluA1 (right, pink). White regions indicate overlap. Yellow arrows indicate examples of presumed synaptic puncta included in analysis. $\boldsymbol{B}$, Box-and-whiskers plot of the density of CA1 synaptic GluA1 puncta in controls and xCT ${ }^{-1-}$ mutants. C, Representative whole-cell patch-clamp $\left(-70 \mathrm{mV}\right.$ ) recordings from control (black) and xCT ${ }^{-1-}$ mutant (red) CA1 neurons. Recordings on left are AMPAR mEPSCs recorded in the presence of TTX and bicuculline. Recordings on the right are GABA $A_{A} \mathrm{mIPSC}$ recorded in the presence of TTX and NBQX. Calibration: Horizontal, 1 min; vertical, 5 pA. D, Box-and-whiskers plot of mEPSC and mIPSC frequencies. Red dot indicates a single mEPSC frequency outlier.

A

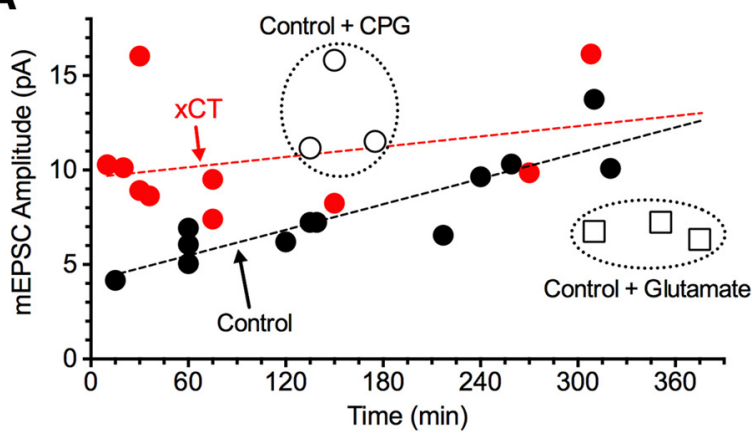

B

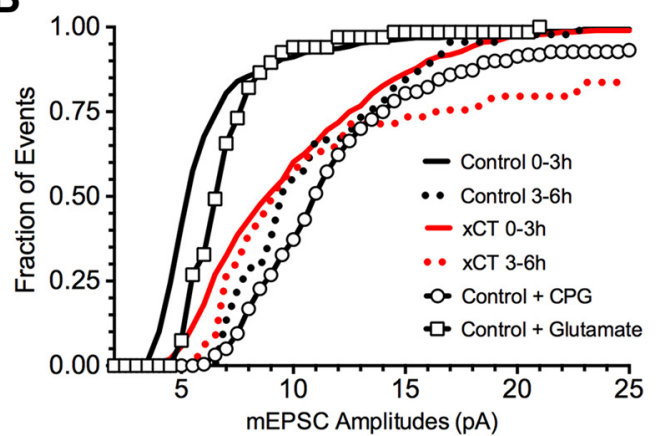

Figure 8. $x \mathrm{xT}^{-1-}$ mutant $\mathrm{mEPSC}$ amplitudes are phenocopied by incubation of control hippocampal slices in glutamate-free aCSF, or $2 \mathrm{~h}$ exposure to the $x C T$ inhibitor $C P G$. $A$, $m E$ EPSC amplitudes recorded from $\mathrm{xCT}^{-1-}$ mutant (red) or control (black) CA1 neurons, relative to the time the slices were incubated in aCSF before the recording. Control mEPSC amplitudes increased significantly as slices were incubated in glutamate-free aCSF. However, this increase did not occur if slices were incubated in aCSF containing glutamate. $\mathrm{mEPSC}$ amplitudes were increased to xCT ${ }^{-1-}$ mutant levels after only $2 \mathrm{~h}$ incubation in aCSF containing CPG. B, Cumulative frequency histograms showing shift of mEPSC amplitudes under various conditions: control $\mathrm{mEPSCs}$ recorded after $0-3 \mathrm{~h}$ in glutamate-free aCSF (black line), control mEPSCs recorded after $3-6$ h in glutamate-free aCSF (dotted line), $\mathrm{xCT}^{-1-}$ mutant mEPSCs recorded after 0 - $3 \mathrm{~h}^{\text {in }}$ glutamate-free aCSF (red line), $\mathrm{xCT}^{-1-}$ mutant $\mathrm{mEPSC}$ (secorded after 3-6 h in glutamate-free aCSF (red dotted line), control mEPSCs recorded in glutamate-free aCSF containing CPG (black line with circles), and control mEPSCs recorded in aCSF containing glutamate (black line with squares).

First, we hypothesized that mEPSC amplitudes in control slices would gradually increase as the tissue was incubated in glutamate-free aCSF. If $\mathrm{xCT}$ suppresses postsynaptic AMPA receptor abundance via glutamate, then mEPSCs recorded in slices from control mice should increasingly phenocopy the $\mathrm{xCT}^{-1-}$ mutant slices as extracellular glutamate is washed from the slice by glutamate-free aCSF. Consistent with this idea, we observed that mEPSC amplitudes increased over time when slices were incubated in glutamate-free aCSF (Fig. $8 A ; 0.02 \pm 0.004 \mathrm{pA} / \mathrm{min}$; linear regression, $p<0.001)$. In contrast, $\mathrm{xCT}^{-1-}$ mutant mEPSCs did not significantly increase under the same conditions (Fig. $8 A ; 0.01 \pm 0.008 \mathrm{pA} / \mathrm{min}$; linear regression $p=0.466$ ). If we compare the entire mEPSC amplitude distributions (Fig. $8 B$ ), we see that distributions of control mEPSC amplitudes recorded af- 
ter 3-6 h in glutamate-free aCSF were statistically indistinguishable from distributions of $\mathrm{xCT}^{-1-}$ mutant mEPSC amplitudes (Kolmogorov-Smirnov test, $p=0.271$ ). In other words, controls phenocopied $\mathrm{xCT}^{-1-}$ mutants after $3 \mathrm{~h}$ in glutamate-free aCSF.

To confirm that the increase in mEPSC amplitude over time was truly due to lack of glutamate, we also recorded mEPSC amplitudes from control slices incubated in $5 \mu \mathrm{M}$ glutamate for $4.5 \mathrm{~h}$, followed by normal (glutamate-free) aCSF for at least 15 min to allow recovery from any receptor desensitization. Glutamate $(5 \mu \mathrm{M})$ is the measured concentration of extracellular glutamate in our control hippocampal slices (G. Ojeda-Torres, L.E. Williams, D.E. Featherstone, and S.A. Shippy, unpublished observations). Consistent with the idea that the increase in mEPSC amplitudes over time was due to loss of extracellular glutamate, there was no increase in control slice mEPSC amplitude when aCSF contained $5 \mu \mathrm{M}$ glutamate, even after $5 \mathrm{~h}$ (Fig. $8 A, B$ ).

Finally, to check whether the increased mEPSC amplitudes could really be attributed to loss of xCT activity, we bathed control slices in aCSF containing the CPG $(50 \mu \mathrm{M})$. As expected, CPG caused a statistically significant enhancement of mEPSC amplitudes (Kolmogorov-Smirnov test, $p<0.001$ ), such that CPGtreated controls phenocopied $\mathrm{xCT}^{-1-}$ mutants within $3 \mathrm{~h}$ (Fig. $8 A, B)$.

\section{Discussion}

$\mathrm{xCT}$ is highly expressed in brain tissue (Pow, 2001; Sato et al., 2002; Burdo et al., 2006; La Bella et al., 2007). Our work suggests that xCT-secreted glutamate suppresses postsynaptic AMPA receptor abundance in hippocampal CA3-CA1 synapses. We examined $\mathrm{xCT}$ function in the hippocampus for several reasons. First, $\mathrm{xCT}$ mRNA expression is particularly strong in the hippocampus, and xCT activity has been observed specifically in astrocytes surrounding CA1 neurons (Pow, 2001). Second, extracellular glutamate levels measured in the hippocampus are not calcium dependent, consistent with the idea that extracellular glutamate is primarily regulated by nonsynaptic release mechanisms like xCT. Indeed, extracellular glutamate concentrations are reduced by $60 \%$ in the hippocampus of $\mathrm{xCT}$ mutant mice, without detectable cell death (De Bundel et al., 2011). Third, xCT mutant mice show behavioral alterations consistent with a change in hippocampal function (De Bundel et al., 2011), even though it remains unclear whether some of these changes are definitively attributable to loss of xCT (McCullagh and Featherstone, 2014). Further, Li et al. (2012) reported that xCT mutant mice show altered contextual fear, passive contextual avoidance memory, and reduced hippocampal CA3-CA1 synaptic LTP (Li et al., 2012). The LTP phenotype was not replicated by acute exposure to the $\mathrm{xCT}$ blocker CPG (Li et al., 2012), but this negative result is consistent with the idea that $\mathrm{xCT}$-dependent synaptic changes take hours, as seen in Drosophila (Augustin et al., 2007) and the present study. We conclude, based on our data, that XCT-mediated glutamate secretion in the hippocampus suppresses postsynaptic AMPA receptor abundance in CA1 neurons, and thereby CA3-CA1 synaptic transmission. However, presynaptic function was not a focus of our study, and we cannot completely rule out changes in presynaptic function. Either way, xCT-mediated synapse modulation is potentially very strong, easily comparable to or exceeding changes following LTP or LTD.

How does xCT-secreted glutamate trigger loss of postsynaptic AMPA receptors? In Drosophila, glutamate secreted by the xCT homolog "genderblind" appears to directly interact with postsynaptic glutamate receptors to cause constitutive desensitization and subsequent removal of those receptors from the synapse (Au- gustin et al., 2007; Chen et al., 2009). This is unlikely to be the mechanism at work in CA3-CA1 synapses, however, where GLTtype glutamate uptake transporters strongly buffer the glutamate in the synaptic cleft (Jabaudon et al., 1999; Lozovaya et al., 2004). If xCT-secreted glutamate suppressed CA1 glutamate receptors via desensitization, as appears to be the case in Drosophila, we would also expect to see a dramatic increase in NMDAdependent currents in $\mathrm{xCT}^{-/-}$mutants, surpassing even the large increase we measured for AMPAR-dependent sEPSCs (Fig. $5)$, since NMDA receptors desensitize at even lower concentrations than AMPA receptors (for review, see Featherstone and Shippy, 2008). However, our preliminary data show no significant difference between NMDA receptor currents (recorded at $+50 \mathrm{mV}$ ) in control and $\mathrm{xCT}^{-1-}$ mutant CA1 neurons (control $\mathrm{NMDA}$ sEPSC $=57.2 \pm 1.9 \mathrm{pA}, N=6 ; \mathrm{xCT}^{-1-} \mathrm{NMDA} \mathrm{sEPSC}=$ $40.48 \pm 15.31 \mathrm{pA}, N=2 ; p=0.08$; control NMDA EPSC $=$ $449.2 \pm 88.0 \mathrm{pA}, N=6 . \mathrm{xCT}: 344.8 \pm 32.7 \mathrm{pA}, N=2 ; p=0.54)$. Therefore, we think it more likely that xCT-mediated modulation of CA3-CA1 synapses involves extrasynaptic mGluRs coupled to pathways modulating CA1 postsynaptic AMPA receptor abundance. This hypothesis fits nicely with previous knowledge. For example, CA3-CA1 synapses display mGluR-dependent LTD (Oliet et al., 1997; Overstreet et al., 1997; Palmer et al., 1997). mGluR-dependent LTD in hippocampal CA1 neurons occurs when activation of Group I mGluRs by extrasynaptic glutamate triggers a series of intracellular signaling events leading to reduced postsynaptic glutamate receptor expression and altered trafficking (Gladding et al., 2009). If xCT activity in vivo contributes to constitutive mGluR-dependent LTD in CA1 neurons, then loss of xCT would be expected to cause increased postsynaptic glutamate receptor abundance exactly as we observed.

If xCT-mediated suppression of glutamatergic synapse strength in the hippocampus occurred via mGluRs, it would highlight a growing "theme" for the role of xCT in the brain. For example, drug-seeking behavior following withdrawal is thought to involve strengthened glutamatergic transmission between the $\mathrm{PFC}$ and the core of the nucleus accumbens (NA). In rats, repeated self-administration of cocaine followed by withdrawal leads to reduced $\mathrm{xCT}$ and extracellular glutamate in the NA (Baker et al., 2003; Knackstedt et al., 2010). This, in turn, is thought to reduce activation of mGluRs and lead to synaptic strengthening. Consistent with this, activation of $\mathrm{xCT}$ with $N$-acetylcysteine or treatment with mGluR 2/3 agonists reduces drug-seeking behavior (Baker et al., 2003; Baptista et al., 2004; Peters and Kalivas, 2006; Kau et al., 2008; Zhou and Kalivas, 2008; Moussawi et al., 2009; Amen et al., 2011). In this case, however, at least some of the $\mathrm{xCT}$-dependent synaptic modulation is thought to be presynaptic, because activation of $\mathrm{xCT}$ by exogenous cystine in the NA decreased EPSC amplitude and mEPSC frequency with no change in mEPSC amplitude, and this effect was blocked by mGluR 2/3 antagonists (Moran et al., 2005). This presynaptic suppression is thought to involve activation of presynaptic potassium channels and inhibition of presynaptic calcium channels (Moussawi and Kalivas, 2010). However, it should be noted that these NA studies did not rule out postsynaptic changes in AMPA receptor abundance such as we observed in the hippocampus, because the postsynaptic changes we observed take several hours to manifest, while the NA experiments examined pharmacologically induced effects over just a few minutes. Also, there is quite a bit of evidence for increased surface AMPA receptor expression and alterations in AMPA receptor subunit composition in the NA core during cocaine withdrawal in rodents (for review, see Wolf and Ferrario, 2010; Loweth et al., 2014). Furthermore, infusion of 
ionotropic glutamate receptor agonists into the NA elicits reinstatement of drug seeking (Cornish et al., 1999) while microinjection of AMPA receptor antagonists into the NA blocks reinstatement (Cornish and Kalivas, 2000). Thus, it would not be surprising to ultimately discover that effects of xCT-secreted glutamate involve both presynaptic and postsynaptic mechanisms, depending on the synapse, but all data suggest that the end result in any case is suppression of glutamatergic synapse strength.

Accepting that $\mathrm{xCT}$ is a major paracrine regulator of glutamatergic synapse strength in vivo, it is useful to ask what regulates $\mathrm{xCT}$ expression and activity. Most studies of xCT expression and activity used cultured cells and treatments designed to understand the role of $\mathrm{xCT}$ during pathological oxidative stress, as oxygen itself is a potent modulator of xCT in cultured cells (Bannai et al., 1989; Lewerenz et al., 2012). However, pharmacological manipulation of mGluR 2/3, PKA, PKC, and CaMKII also affect $\mathrm{xCT}$ activity in astrocytes (Tang and Kalivas, 2003), suggesting that xCT may function both upstream and downstream of mGluRs in vivo. $\mathrm{xCT}$ activity in cortical astrocytes also appears to be activated by extracellular cystine and inhibited by lactic acid (Koyama et al., 2000), adding these to the list of potential modulators. Ultimately, this is an area ripe for exploration, and likely to provide significant insights with regard to modulation of brain function.

It is also interesting to note the effects of standard (glutamatefree) aCSF on the size of CA3-CA1 synaptic currents over time. This effect is important to consider when planning slice experiments, or interpreting the effects of applied treatments.

In summary, we have provided the first detailed description of synaptic changes in an xCT mutant mammal. Both patch-clamp electrophysiology and immunohistochemistry show that hippocampal CA3-CA1 synapses in $\mathrm{xCT}$ knock-out mice contain more postsynaptic AMPA receptors, leading to strongly enhanced glutamatergic neurotransmission. This effect could be suppressed by incubating brain tissue in aCSF containing glutamate, and phenocopied by incubating brain tissue in the $\mathrm{xCT}$ inhibitor CPG or aCSF without glutamate, consistent with the idea that the increase in AMPA receptor abundance was due to loss of $\mathrm{xCT}$-secreted glutamate. Thus, we conclude that $\mathrm{xCT}$ in hippocampal astrocytes secretes glutamate that in turn triggers loss of postsynaptic AMPA receptors to suppress synapse strength.

\section{References}

Amen SL, Piacentine LB, Ahmad ME, Li SJ, Mantsch JR, Risinger RC, Baker DA (2011) Repeated N-acetyl cysteine reduces cocaine seeking in rodents and craving in cocaine-dependent humans. Neuropsychopharmacology 36:871-878. CrossRef Medline

Augustin H, Grosjean Y, Chen K, Sheng Q, Featherstone DE (2007) Nonvesicular release of glutamate by glial $\mathrm{xCT}$ transporters suppresses glutamate receptor clustering in vivo. J Neurosci 27:111-123. CrossRef Medline

Baker DA, Xi ZX, Shen H, Swanson CJ, Kalivas PW (2002) The origin and neuronal function of in vivo nonsynaptic glutamate. J Neurosci 22:91349141. Medline

Baker DA, McFarland K, Lake RW, Shen H, Tang XC, Toda S, Kalivas PW (2003) Neuroadaptations in cystine-glutamate exchange underlie cocaine relapse. Nat Neurosci 6:743-749. CrossRef Medline

Bannai S, Sato H, Ishii T, Sugita Y (1989) Induction of cystine transport activity in human fibroblasts by oxygen. J Biol Chem 264:18480-18484. Medline

Baptista MA, Martin-Fardon R, Weiss F (2004) Preferential effects of the metabotropic glutamate $2 / 3$ receptor agonist LY379268 on conditioned reinstatement versus primary reinforcement: comparison between cocaine and a potent conventional reinforcer. J Neurosci 24:4723-4727. CrossRef Medline
Bridges R, Lutgen V, Lobner D, Baker DA (2012) Thinking outside the cleft to understand synaptic activity: contribution of the cystine-glutamate antiporter (System xc-) to normal and pathological glutamatergic signaling. Pharmacol Rev 64:780-802. CrossRef Medline

Burdo J, Dargusch R, Schubert D (2006) Distribution of the cystine/glutamate antiporter system $\mathrm{x}-\mathrm{c}$ in the brain, kidney, and duodenum. J Histochem Cytochem 54:549-557. CrossRef Medline

Chen K, Augustin H, Featherstone DE (2009) Effect of ambient extracellular glutamate on Drosophila glutamate receptor trafficking and function. J Comp Physiol A Neuroethol Sens Neural Behav Physiol 195:21-29. CrossRef Medline

Chen Y, Swanson RA (2003) The glutamate transporters EAAT2 and EAAT3 mediate cysteine uptake in cortical neuron cultures. J Neurochem 84:1332-1339. CrossRef Medline

Chillarón J, Roca R, Valencia A, Zorzano A, Palacín M (2001) Heteromeric amino acid transporters: biochemistry, genetics, and physiology. Am J Physiol Renal Physiol 281:F995-F1018. Medline

Cornish JL, Kalivas PW (2000) Glutamate transmission in the nucleus accumbens mediates relapse in cocaine addiction. J Neurosci 20:RC89. Medline

Cornish JL, Duffy P, Kalivas PW (1999) A role for nucleus accumbens glutamate transmission in the relapse to cocaine-seeking behavior. Neuroscience 93:1359-1367. CrossRef Medline

De Bundel D, Schallier A, Loyens E, Fernando R, Miyashita H, Van Liefferinge J, Vermoesen K, Bannai S, Sato H, Michotte Y, Smolders I, Massie A (2011) Loss of system $\mathrm{x}(\mathrm{c})$ - does not induce oxidative stress but decreases extracellular glutamate in hippocampus and influences spatial working memory and limbic seizure susceptibility. J Neurosci 31:5792-5803. CrossRef Medline

Elias GM, Funke L, Stein V, Grant SG, Bredt DS, Nicoll RA (2006) Synapsespecific and developmentally regulated targeting of AMPA receptors by a family of MAGUK scaffolding proteins. Neuron 52:307-320. CrossRef Medline

Featherstone DE, Shippy SA (2008) Regulation of synaptic transmission by ambient extracellular glutamate. Neuroscientist 14:171-181. CrossRef Medline

Fernández E, Jiménez-Vidal M, Calvo M, Zorzano A, Tebar F, Palacín M, Chillarón J (2006) The structural and functional units of heteromeric amino acid transporters. The heavy subunit rBAT dictates oligomerization of the heteromeric amino acid transporters. J Biol Chem 281:2655226561. CrossRef Medline

Fillenz M (2005) In vivo neurochemical monitoring and the study of behaviour. Neurosci Biobehav Rev 29:949-962. CrossRef Medline

Gladding CM, Fitzjohn SM, Molnár E (2009) Metabotropic glutamate receptor-mediated long-term depression: molecular mechanisms. Pharmacol Rev 61:395-412. CrossRef Medline

Grosjean Y, Grillet M, Augustin H, Ferveur JF, Featherstone DE (2008) A glial amino-acid transporter controls synapse strength and courtship in Drosophila. Nat Neurosci 11:54-61. CrossRef Medline

Hosoya K, Tomi M, Ohtsuki S, Takanaga H, Saeki S, Kanai Y, Endou H, Naito M, Tsuruo T, Terasaki T (2002) Enhancement of L-cystine transport activity and its relation to $\mathrm{xCT}$ gene induction at the blood-brain barrier by diethyl maleate treatment. J Pharmacol Exp Ther 302:225-231. CrossRef Medline

Jabaudon D, Shimamoto K, Yasuda-Kamatani Y, Scanziani M, Gähwiler BH, Gerber U (1999) Inhibition of uptake unmasks rapid extracellular turnover of glutamate of nonvesicular origin. Proc Natl Acad Sci U S A 96: 8733-8738. CrossRef Medline

Kanai Y, Endou H (2001) Heterodimeric amino acid transporters: molecular biology and pathological and pharmacological relevance. Curr Drug Metab 2:339-354. CrossRef Medline

Kau KS, Madayag A, Mantsch JR, Grier MD, Abdulhameed O, Baker DA (2008) Blunted cystine-glutamate antiporter function in the nucleus accumbens promotes cocaine-induced drug seeking. Neuroscience 155: 530-537. CrossRef Medline

Kim JY, Kanai Y, Chairoungdua A, Cha SH, Matsuo H, Kim DK, Inatomi J, Sawa H, Ida Y, Endou H (2001) Human cystine/glutamate transporter: cDNA cloning and upregulation by oxidative stress in glioma cells. Biochim Biophys Acta 1512:335-344. CrossRef Medline

Kimelberg HK, Goderie SK, Higman S, Pang S, Waniewski RA (1990) Swelling-induced release of glutamate, aspartate, and taurine from astrocyte cultures. J Neurosci 10:1583-1591. Medline 
Knackstedt LA, Melendez RI, Kalivas PW (2010) Ceftriaxone restores glutamate homeostasis and prevents relapse to cocaine seeking. Biol Psychiatry 67:81-84. CrossRef Medline

Koyama Y, Kimura Y, Hashimoto H, Matsuda T, Baba A (2000) L-lactate inhibits L-cystine/L-glutamate exchange transport and decreases glutathione content in rat cultured astrocytes. J Neurosci Res 59:685-691. CrossRef Medline

La Bella V, Valentino F, Piccoli T, Piccoli F (2007) Expression and developmental regulation of the cystine/glutamate exchanger (xc-) in the rat. Neurochem Res 32:1081-1090. CrossRef Medline

Lee HK, Takamiya K, Kameyama K, He K, Yu S, Rossetti L, Wilen D, Huganir RL (2007) Identification and characterization of a novel phosphorylation site on the GluR1 subunit of AMPA receptors. Mol Cell Neurosci 36:86-94. CrossRef Medline

Lewerenz J, Maher P, Methner A (2012) Regulation of xCT expression and system x (c) (-) function in neuronal cells. Amino Acids 42:171-179. CrossRef Medline

Li Y, Tan Z, Li Z, Sun Z, Duan S, Li W (2012) Impaired long-term potentiation and long-term memory deficits in xCT-deficient sut mice. Biosci Rep 32:315-321. CrossRef Medline

Loweth JA, Tseng KY, Wolf ME (2014) Adaptations in AMPA receptor transmission in the nucleus accumbens contributing to incubation of cocaine craving. Neuropharmacology 76:287-300. CrossRef Medline

Lozovaya N, Melnik S, Tsintsadze T, Grebenyuk S, Kirichok Y, Krishtal O (2004) Protective cap over CA1 synapses: extrasynaptic glutamate does not reach the postsynaptic density. Brain Res 1011:195-205. CrossRef Medline

Lu W, Shi Y, Jackson AC, Bjorgan K, During MJ, Sprengel R, Seeburg PH, Nicoll RA (2009) Subunit composition of synaptic AMPA receptors revealed by a single-cell genetic approach. Neuron 62:254-268. CrossRef Medline

Malarkey EB, Parpura V (2008) Mechanisms of glutamate release from astrocytes. Neurochem Int 52:142-154. CrossRef Medline

Massie A, Schallier A, Kim SW, Fernando R, Kobayashi S, Beck H, De Bundel D, Vermoesen K, Bannai S, Smolders I, Conrad M, Plesnila N, Sato H, Michotte Y (2011) Dopaminergic neurons of system xc-deficient mice are highly protected against 6-hydroxydopamine-induced toxicity. FASEB J 25:1359-1369. CrossRef Medline

McBean GJ (2002) Cerebral cystine uptake: a tale of two transporters. Trends Pharmacol Sci 23:299-302. CrossRef Medline

McCullagh EA, Featherstone DE (2014) Behavioral characterization of system xc-mutant mice. Behav Brain Res 265:1-11. CrossRef Medline

Montana V, Malarkey EB, Verderio C, Matteoli M, Parpura V (2006) Vesicular transmitter release from astrocytes. Glia 54:700-715. CrossRef Medline

Moran MM, McFarland K, Melendez RI, Kalivas PW, Seamans JK (2005) Cystine/glutamate exchange regulates metabotropic glutamate receptor presynaptic inhibition of excitatory transmission and vulnerability to cocaine seeking. J Neurosci 25:6389-6393. CrossRef Medline

Moussawi K, Kalivas PW (2010) Group II metabotropic glutamate receptors (mGlu2/3) in drug addiction. Eur J Pharmacol 639:115-122. CrossRef Medline

Moussawi K, Pacchioni A, Moran M, Olive MF, Gass JT, Lavin A, Kalivas PW (2009) N-Acetylcysteine reverses cocaine-induced metaplasticity. Nat Neurosci 12:182-189. CrossRef Medline

Oliet SH, Malenka RC, Nicoll RA (1997) Two distinct forms of long-term depression coexist in CA1 hippocampal pyramidal cells. Neuron 18:969982. CrossRef Medline

Overstreet LS, Pasternak JF, Colley PA, Slater NT, Trommer BL (1997) Metabotropic glutamate receptor mediated long-term depression in developing hippocampus. Neuropharmacology 36:831-844. CrossRef Medline

Palacín M, Nunes V, Font-Llitjós M, Jiménez-Vidal M, Fort J, Gasol E, Pineda
M, Feliubadaló L, Chillarón J, Zorzano A (2005) The genetics of heteromeric amino acid transporters. Physiology 20:112-124. CrossRef Medline

Palmer MJ, Irving AJ, Seabrook GR, Jane DE, Collingridge GL (1997) The group I mGlu receptor agonist DHPG induces a novel form of LTD in the CA1 region of the hippocampus. Neuropharmacology 36:1517-1532. CrossRef Medline

Parpura V, Scemes E, Spray DC (2004) Mechanisms of glutamate release from astrocytes: gap junction "hemichannels," purinergic receptors and exocytotic release. Neurochem Int 45:259-264. CrossRef Medline

Peters J, Kalivas PW (2006) The group II metabotropic glutamate receptor agonist, LY379268, inhibits both cocaine- and food-seeking behavior in rats. Psychopharmacology 186:143-149. CrossRef Medline

Piyankarage SC, Augustin H, Grosjean Y, Featherstone DE, Shippy SA (2008) Hemolymph amino acid analysis of individual Drosophila larvae. Anal Chem 80:1201-1207. CrossRef Medline

Pow DV (2001) Visualising the activity of the cystine-glutamate antiporter in glial cells using antibodies to aminoadipic acid, a selectively transported substrate. Glia 34:27-38. CrossRef Medline

Qin S, Evering MvdZ, Wahono N, Cremers TIFH, Westerink BHC (2013) Monitoring extracellular glutamate in the brain by microdialysis and microsensors. In: Microelectrode biosensors, neuromethods Vol 80 (Marinesco S, Dale N, eds), pp 153-177. New York: Springer.

Sato H, Tamba M, Ishii T, Bannai S (1999) Cloning and expression of a plasma membrane cystine/glutamate exchange transporter composed of two distinct proteins. J Biol Chem 274:11455-11458. CrossRef Medline

Sato H, Tamba M, Kuriyama-Matsumura K, Okuno S, Bannai S (2000) Molecular cloning and expression of human xCT, the light chain of amino acid transport system xc. Antioxid Redox Signal 2:665-671. CrossRef Medline

Sato H, Tamba M, Okuno S, Sato K, Keino-Masu K, Masu M, Bannai S (2002) Distribution of cystine/glutamate exchange transporter, system $\mathrm{x}(\mathrm{c})-$, in the mouse brain. J Neurosci 22:8028-8033. Medline

Sato H, Shiiya A, Kimata M, Maebara K, Tamba M, Sakakura Y, Makino N, Sugiyama F, Yagami K, Moriguchi T, Takahashi S, Bannai S (2005) Redox imbalance in cystine/glutamate transporter-deficient mice. J Biol Chem 280:37423-37429. CrossRef Medline

Savtchenko LP, Rusakov DA (2014) Moderate AMPA receptor clustering on the nanoscale can efficiently potentiate synaptic current. Philos Trans R Soc Lond B Biol Sci 369:20130167. CrossRef Medline

Shinohara K, Honma S, Katsuno Y, Honma K (2000) Circadian release of excitatory amino acids in the suprachiasmatic nucleus culture is $\mathrm{Ca}(2+)$ independent. Neurosci Res 36:245-250. CrossRef Medline

Tang XC, Kalivas PW (2003) Bidirectional modulation of cystine/glutamate exchanger activity in cultured cortical astrocytes. Ann N Y Acad Sci 1003: 472-475. CrossRef Medline

Timmerman W, Westerink BH (1997) Brain microdialysis of GABA and glutamate: what does it signify? Synapse 27:242-261. CrossRef Medline

Verrey F, Closs EI, Wagner CA, Palacin M, Endou H, Kanai Y (2004) CATs and HATs: the SLC7 family of amino acid transporters. Pflügers Arch 447:532-542. CrossRef Medline

Wagner CA, Lang F, Bröer S (2001) Function and structure of heterodimeric amino acid transporters. Am J Physiol Cell Physiol 281:C1077C1093. Medline

Warr O, Takahashi M, Attwell D (1999) Modulation of extracellular glutamate concentration in rat brain slices by cystine-glutamate exchange. J Physiol 514:783-793. CrossRef Medline

Wolf ME, Ferrario CR (2010) AMPA receptor plasticity in the nucleus accumbens after repeated exposure to cocaine. Neurosci Biobehav Rev 35: 185-211. CrossRef Medline

Zerangue N, Kavanaugh MP (1996) Flux coupling in a neuronal glutamate transporter. Nature 383:634-637. CrossRef Medline

Zhou W, Kalivas PW (2008) N-acetylcysteine reduces extinction responding and induces enduring reductions in cue- and heroin-induced drugseeking. Biol Psychiatry 63:338-340. CrossRef Medline 